EASTERN EUROPEAN JOURNAL OF TRANSNATIONAL RELATIONS

2017 Vol. 1 No. 1

DOI: 10.15290/eejtr.2017.01.01.06

David Albert Best ${ }^{1}$

European Legal English Teachers’ Association

\title{
From EULETA (the European Legal English Teachers' Association) News brief: Language \& Law - Traditions, Trends and Perspectives The Bialystok Legal English Centre
}

EULETA was out in force at the third International Language and Law Conference hosted and organised by the Białystok Legal English Centre at the Faculty of Law, University of Białystok, Poland and notably by our EULETA Board officer, Halina Sierocka and her team in the wonderful region of Podlaskie. The high-profile keynote speakers set the tone with extremely engaging lectures pertinent to our field:

Prof. Vijay Bhatia's talk on Reconceptualising teaching of legal communication: Insights from Critical Genre Theory helped to illustrate how a crucial feature of the ELP teacher's role - through raising the awareness and practice of multiple genre types - is to narrow the gap between "academy" and "workplace" by demystifying professional practice and teaching students to "think like a lawyer". English for Legal Purposes teachers, argues Bhatia, are masters of navigating students through genres and preparing them for the interdiscursive nature of legal discourse, and are thus able to bypass the "content" of the discipline (in our case, Law) without detriment to the teaching and learning of the core subject matter.

Prof. Maurizio Gotti's presentation on Globalising trends and discursive changes in the legal field took listeners on a fascinating journey through the culturebound aspects of legal concepts and hence terminology, with a particular focus on the differences of application in international arbitration practices depending on the cultural norms of the jurisdiction concerned. "Flexibility" was the key word as it

1 The President of the European Legal English Teachers’ Association. E-mail: president@euleta. org. 
was demonstrated that each system has to contend with variations in the language[s] used, specificities of legal systems, and socio-political factors, as well as differences in target readership and cultural norms. We were given an enticing glimpse into the Chinese situation, said to use a legal language that has been found more vague and ambiguous than other traditions in arbitration cases. However, perhaps more remarkable was the comparison between Western and Asian traditions, where the latter focuses on conciliation in contrast to litigation, rooted in the Confucian philosophy of harmony and compromise and the terms "li" and "fa", which sum up the spirit of Chinese law (adoption and adaptation), such that mediation between convicted murderers and victims' families is now being used in criminal cases where the death penalty is involved.

Dr. John Olsson kicked off the second day of the conference with a talk on Forensic language and the unknown revealing a whole unknown field to many of those present, that of Forensic linguistics. Olsson debunked the myth that every individual has a fixed "idiolect" to show that we do, in fact, move between varying idiolects continuously, depending on our age, gender, ethnicity, institution or occupation, native speaker status: context is everything and the way we speak modifies as we move through environments and social groups. What happens when a speaker makes language choices? It is "a consequence of a speaker's attempt to construct an identity appropriate to the context of a given interaction" (Moore, 2004, p. 378). This idea was applied to the language choices made by suspects in criminal cases, where the role of the forensic linguist is to analyse - unbiased, for a jury whatever language matter may be available, be it text messages, business letters, police/suspect statements, or suicide notes to uncover the ploys of imitation, disguise and fraud used by criminals.

With the forty-odd presenters and many more conference delegates hailing from every part of the globe, the range and depth of presentation topics was eclectic and impressive and stimulated lively debate on the continuously evolving nature and promising future of our multifaceted and ever-growing field of activity.

Several members of the EULETA Board were at the conference while many EULETA members actively participated by giving papers and chairing several of the parallel sessions. Compliments to Białystok Legal English Centre for the excellent organisation!

\section{REFERENCES}

Moore, E. (2004). Sociolinguistic Style: A Multidimensional Resource for Shared Identity Creation. The Canadian Journal of Linguistics / La Revue Canadienne de Linguistique, 49(3), 375-396. https://doi.org/10.1353/cj1.2006.0006 